
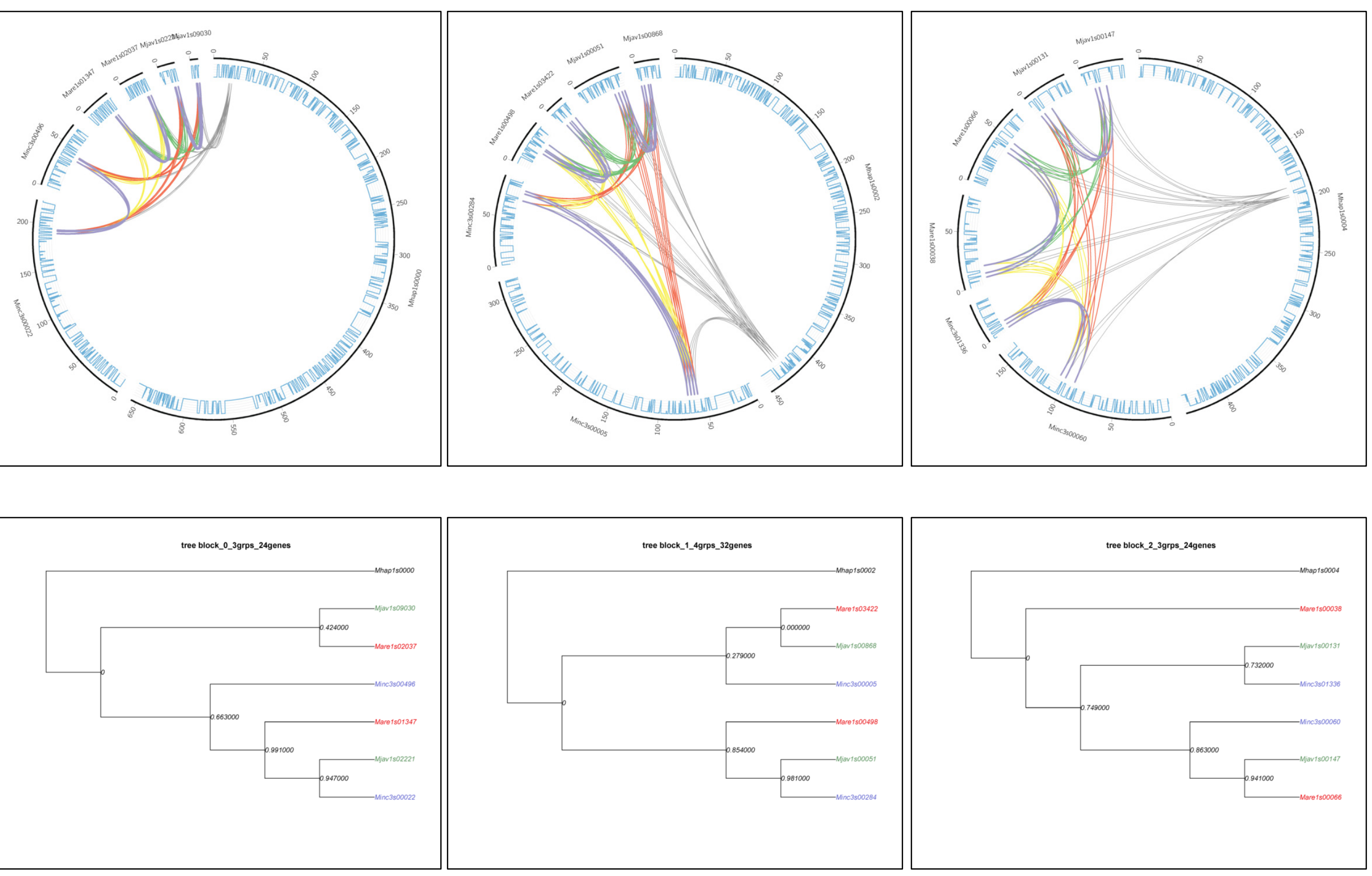

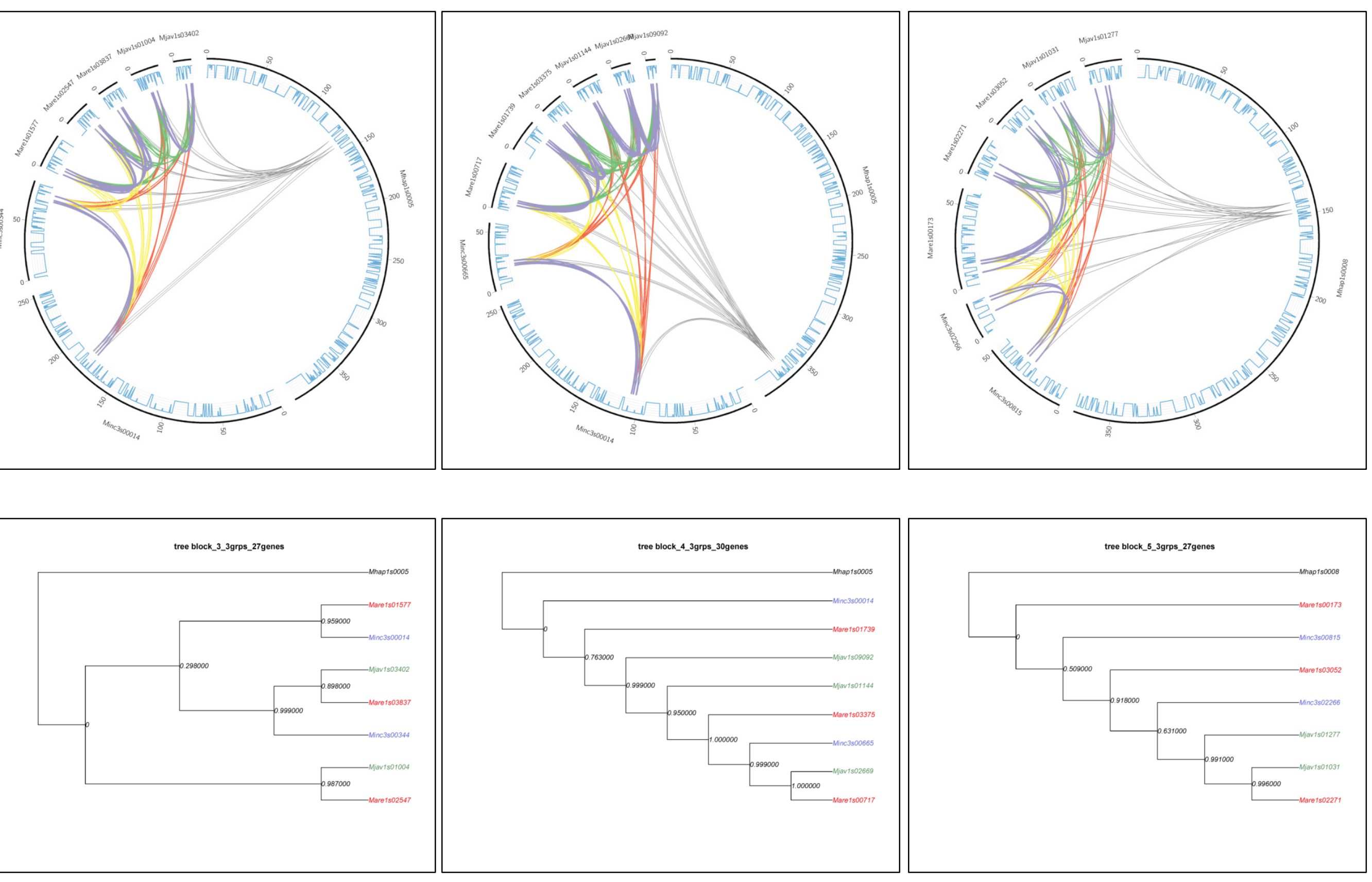

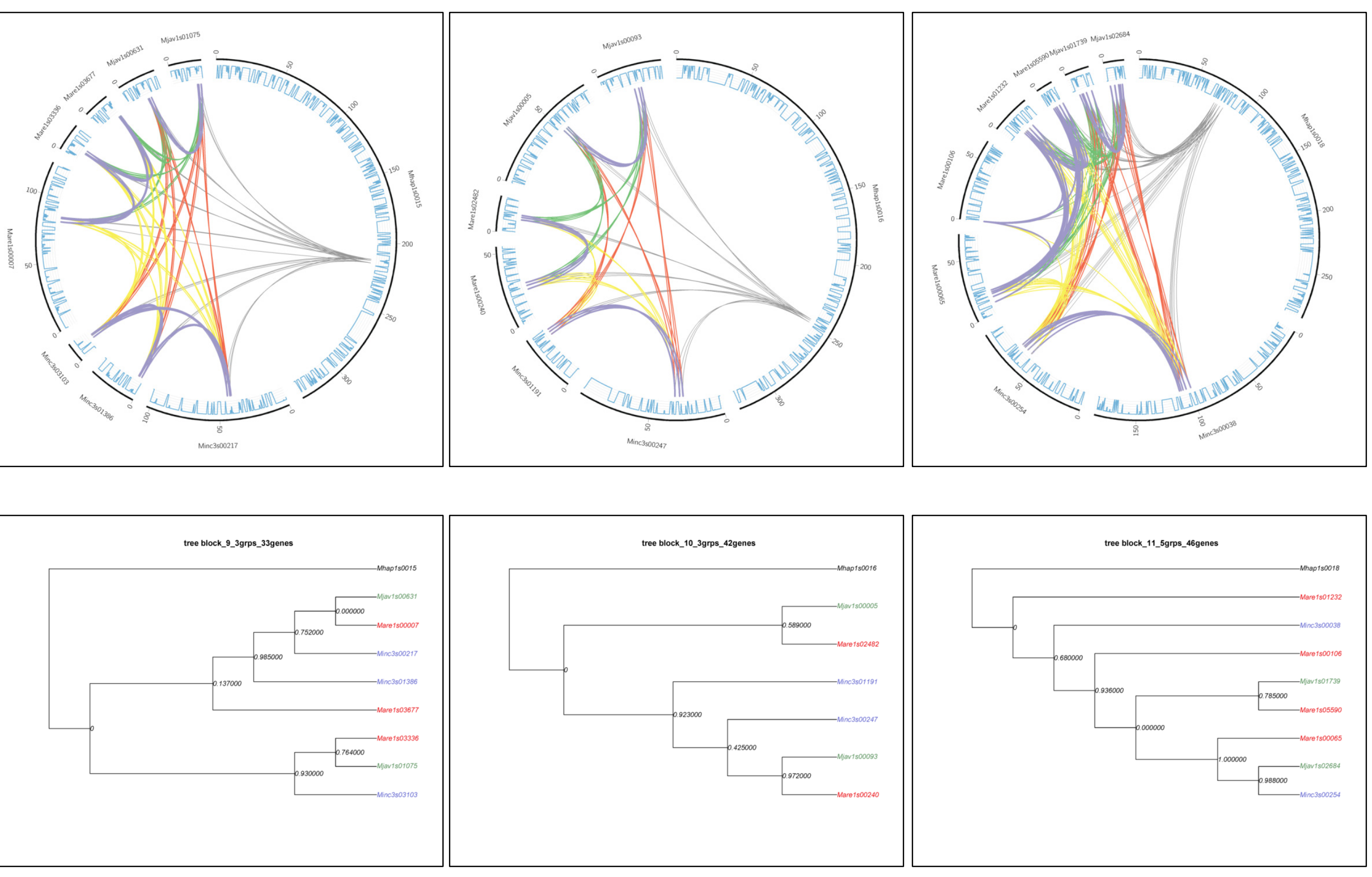

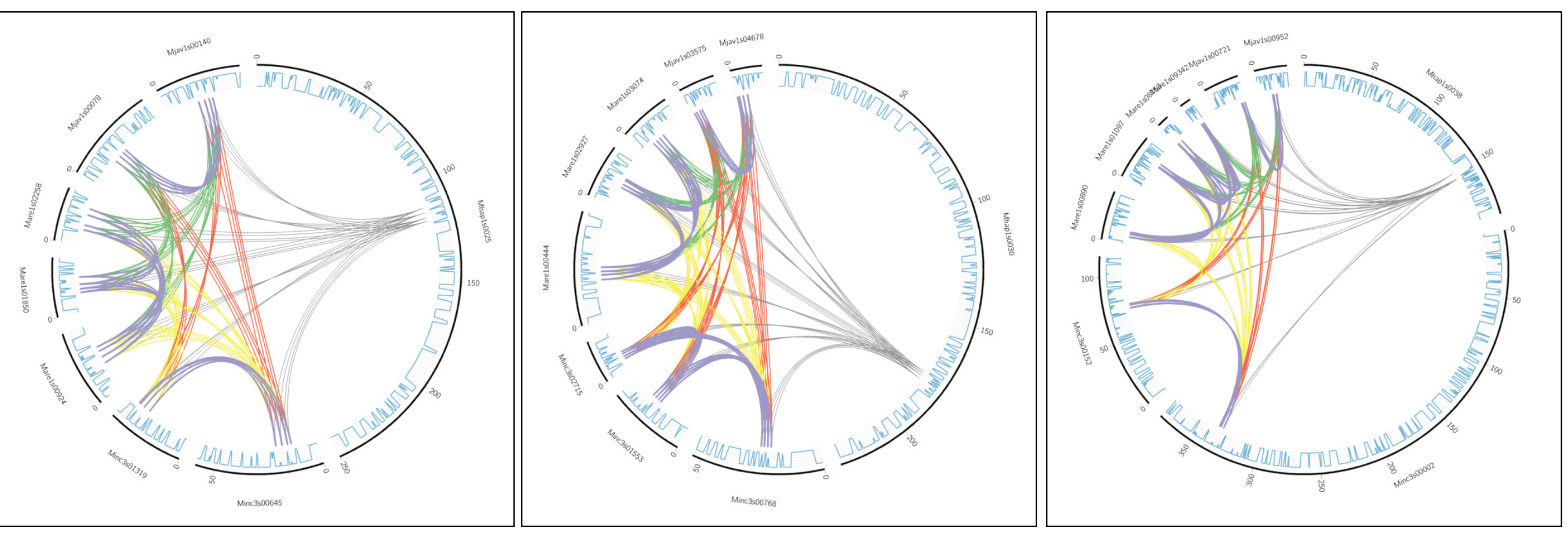

tree block_15_4grps_36genes

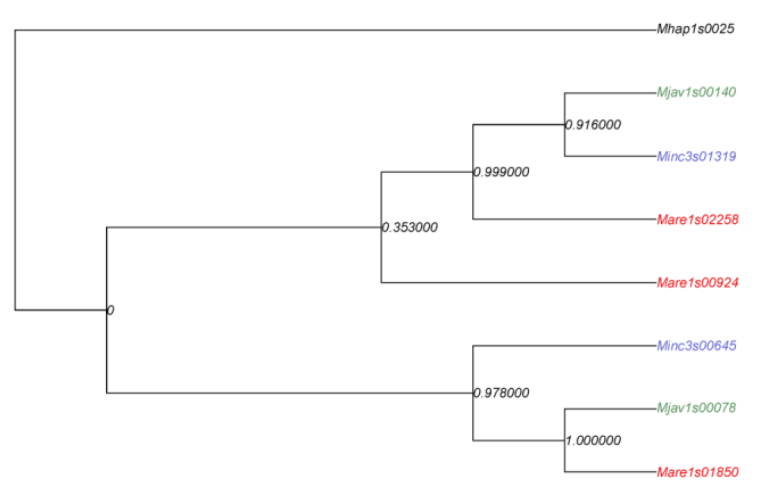

tree block_16_4grps_40genes

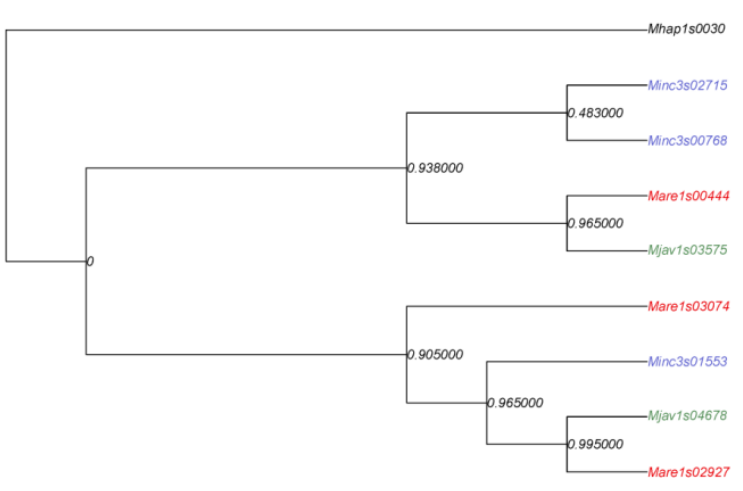

tree block_17_3grps_30genes

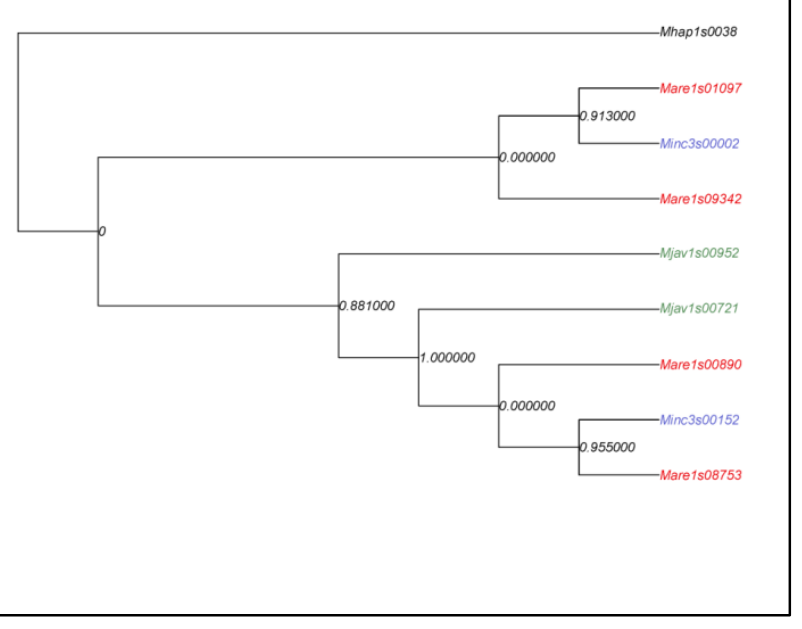



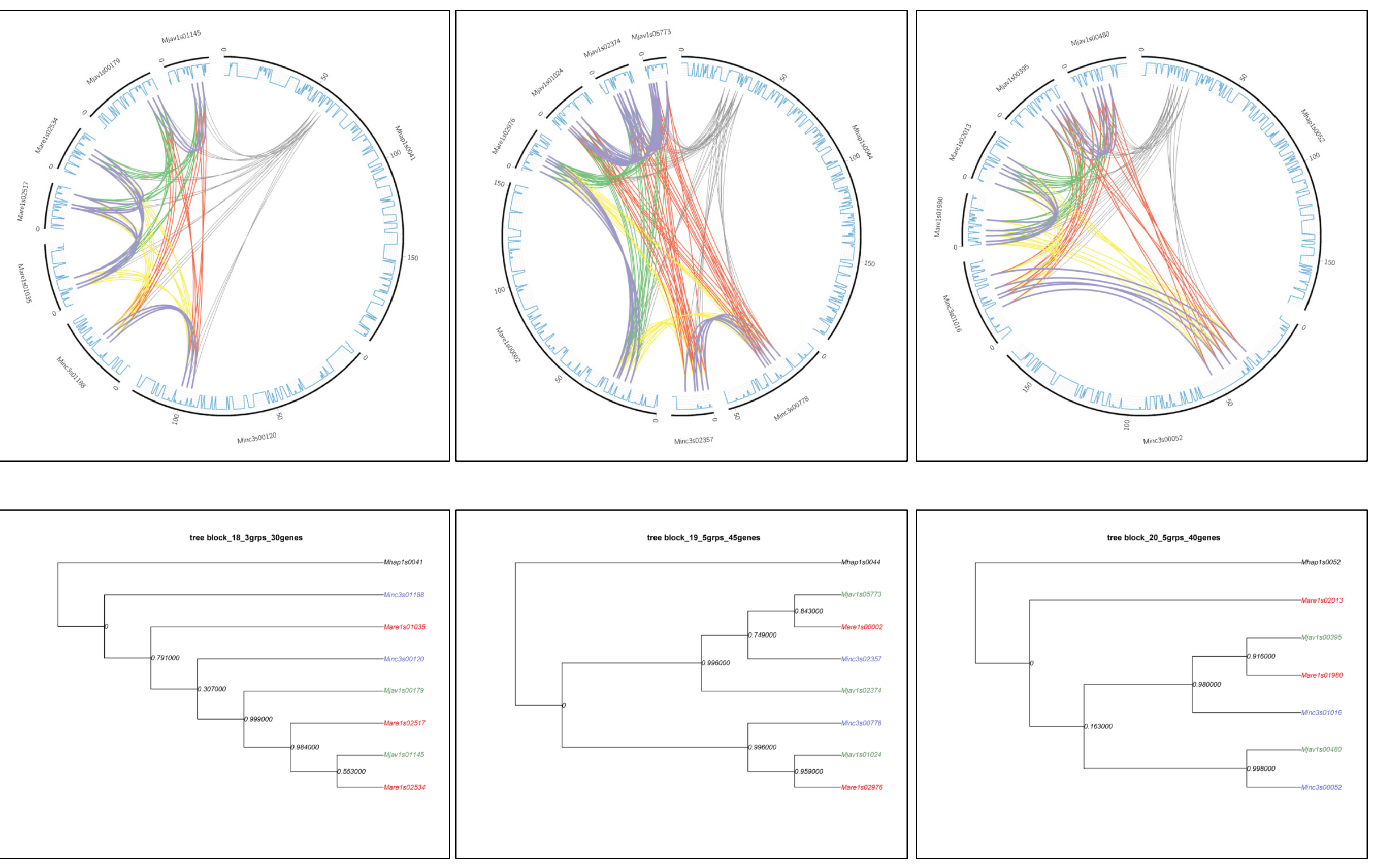

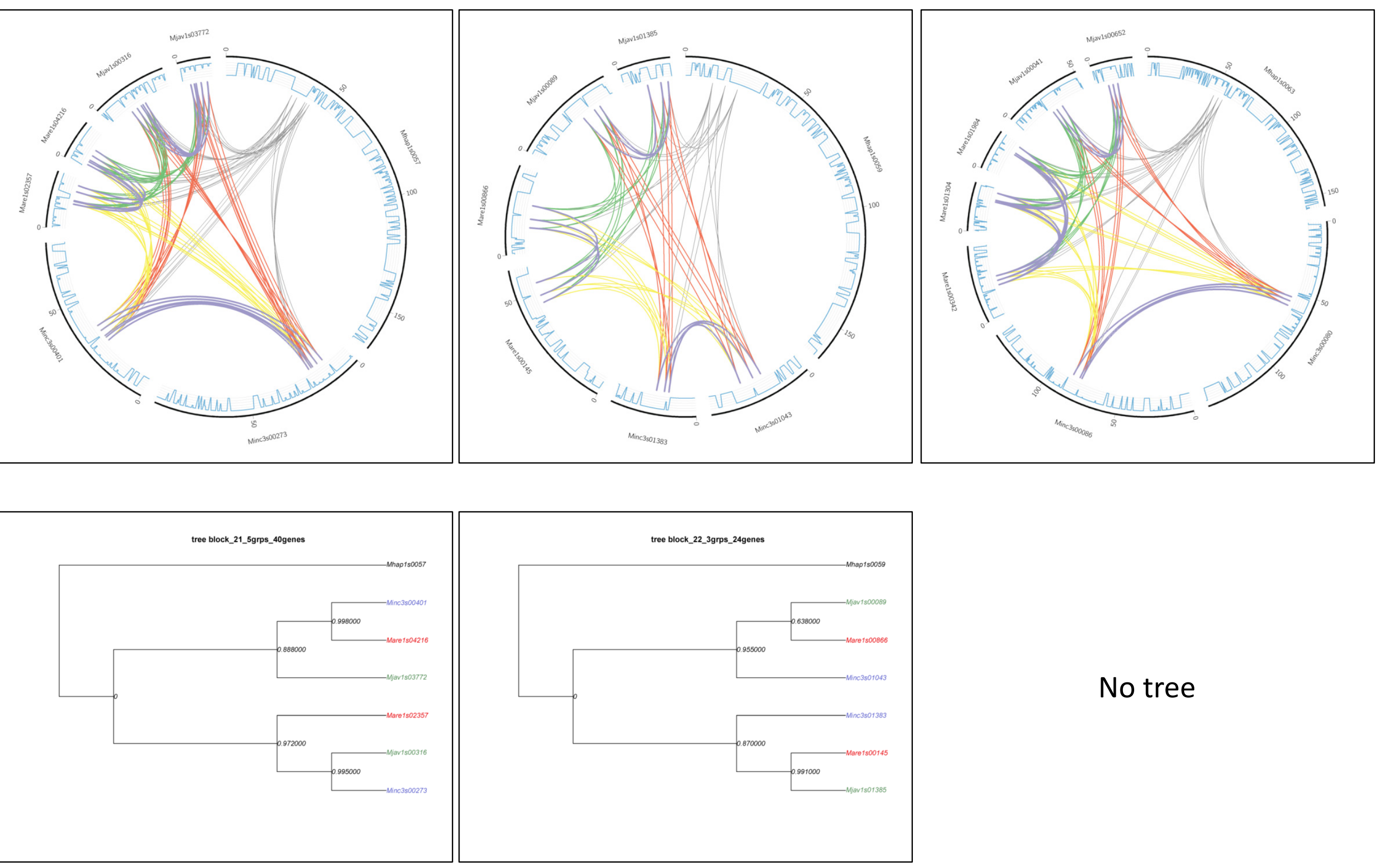

\section{No tree}



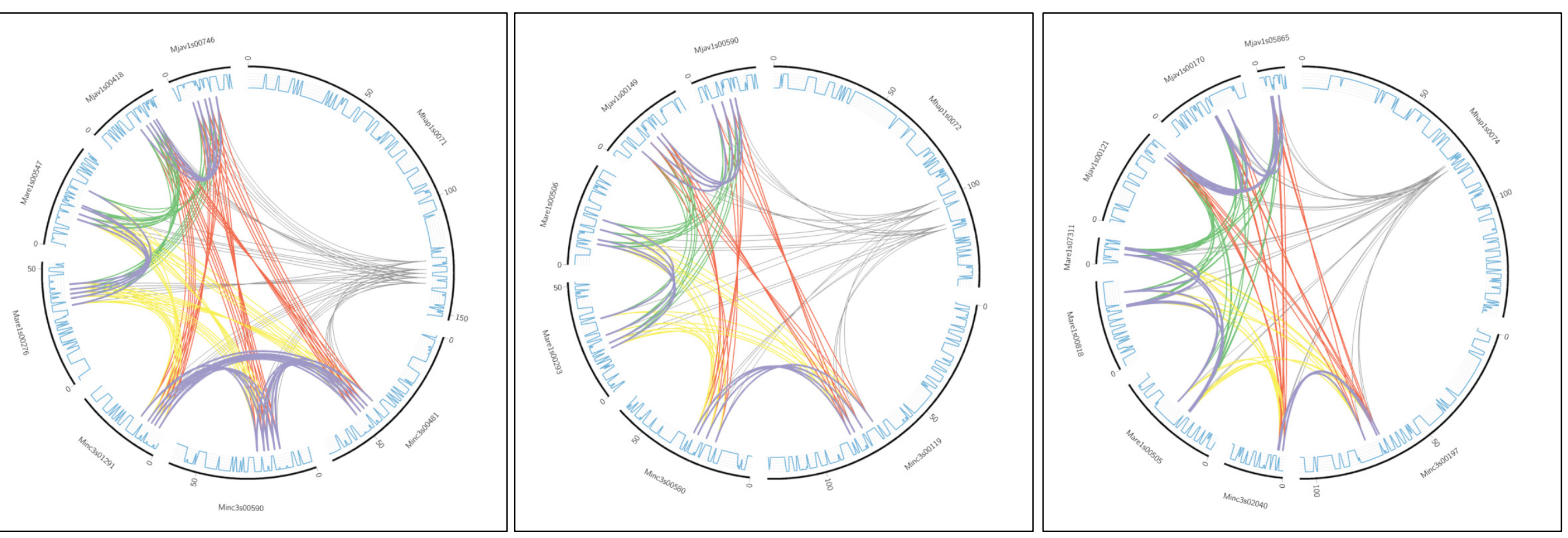

tree block_24_5grps_45genes

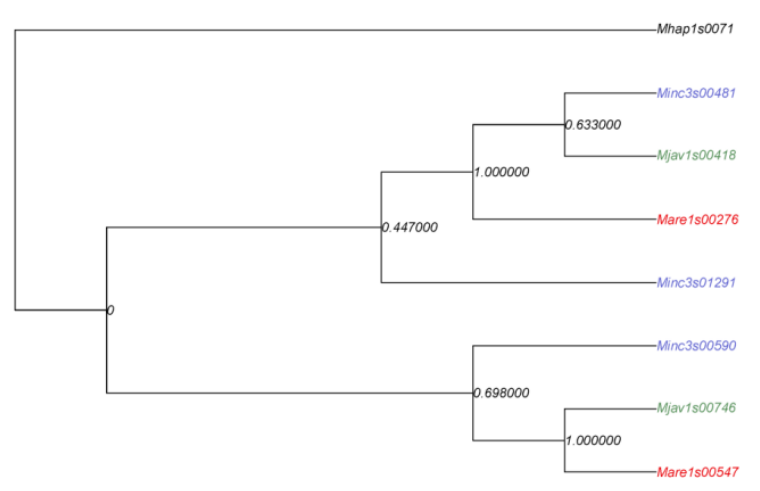

tree block_25_4grps_32genes

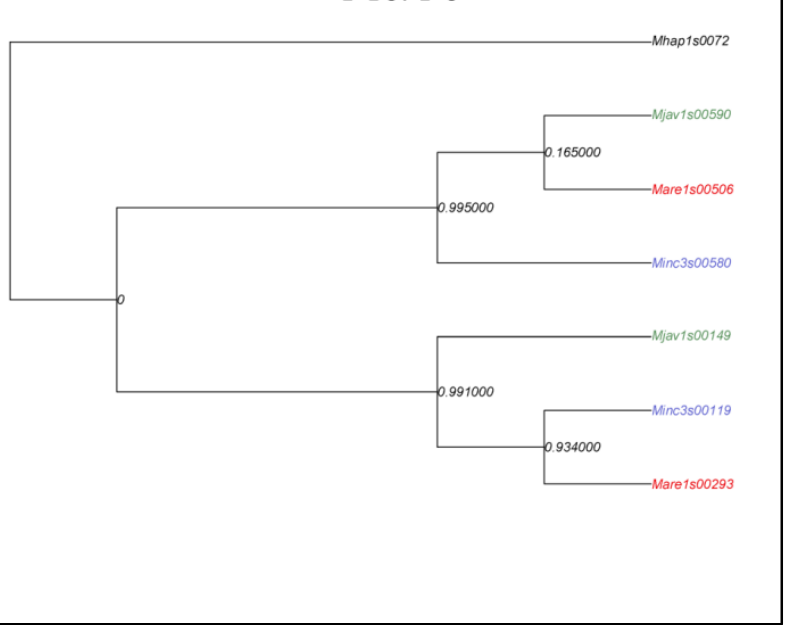

tree block_26_3grps_30genes

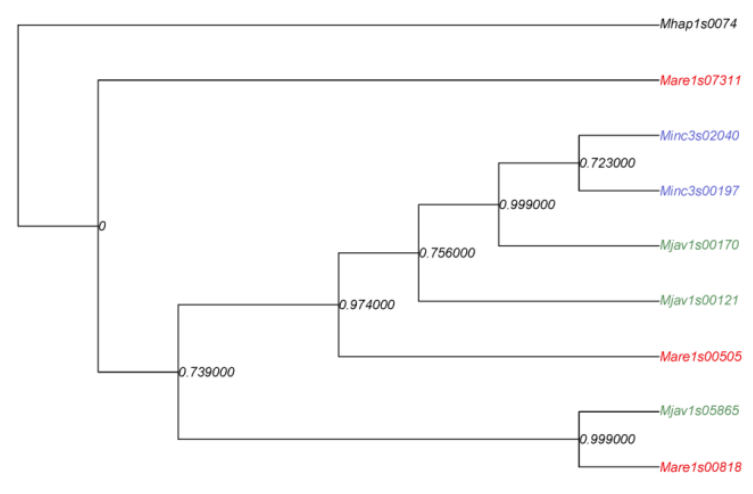



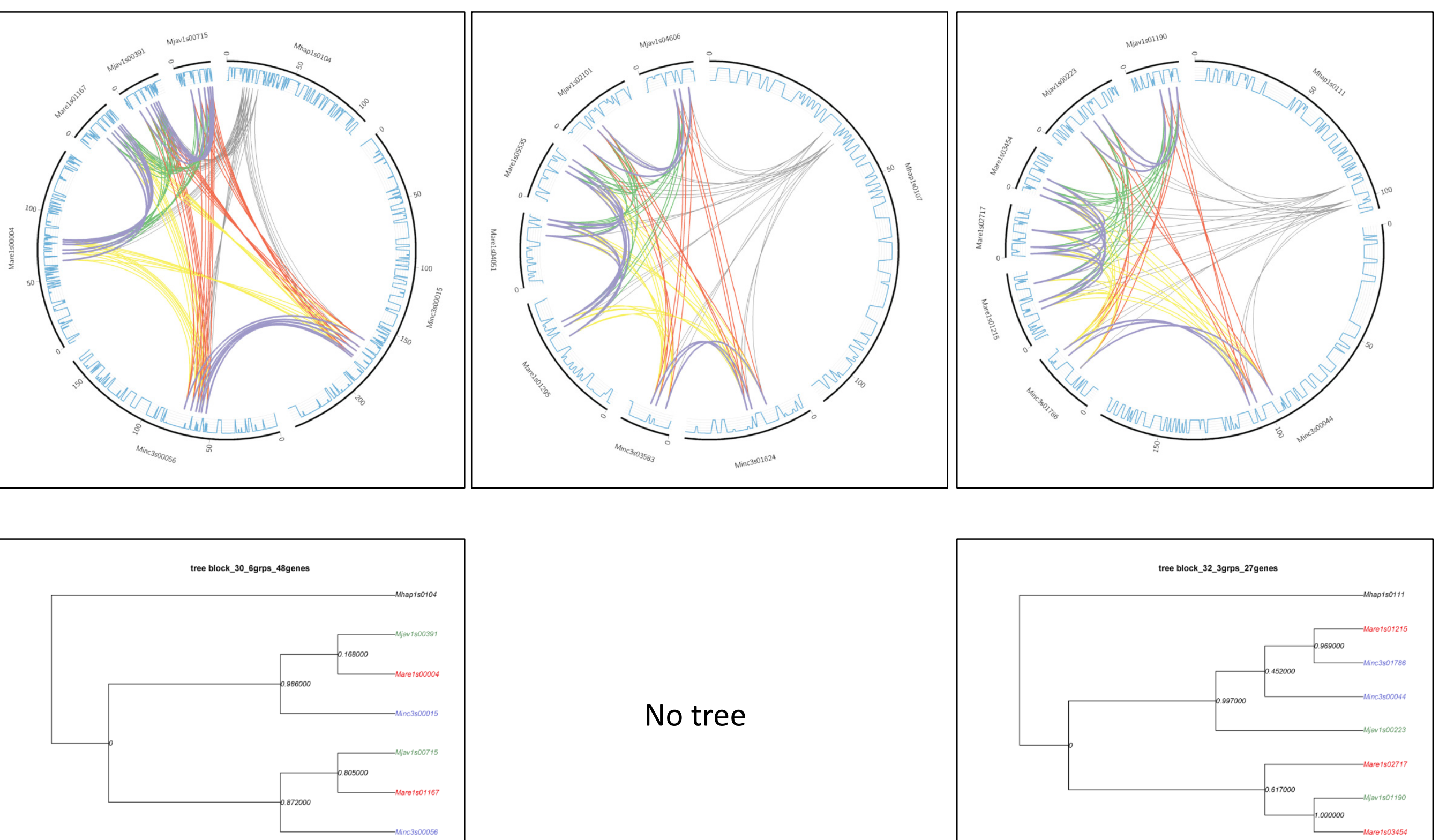

\section{No tree}

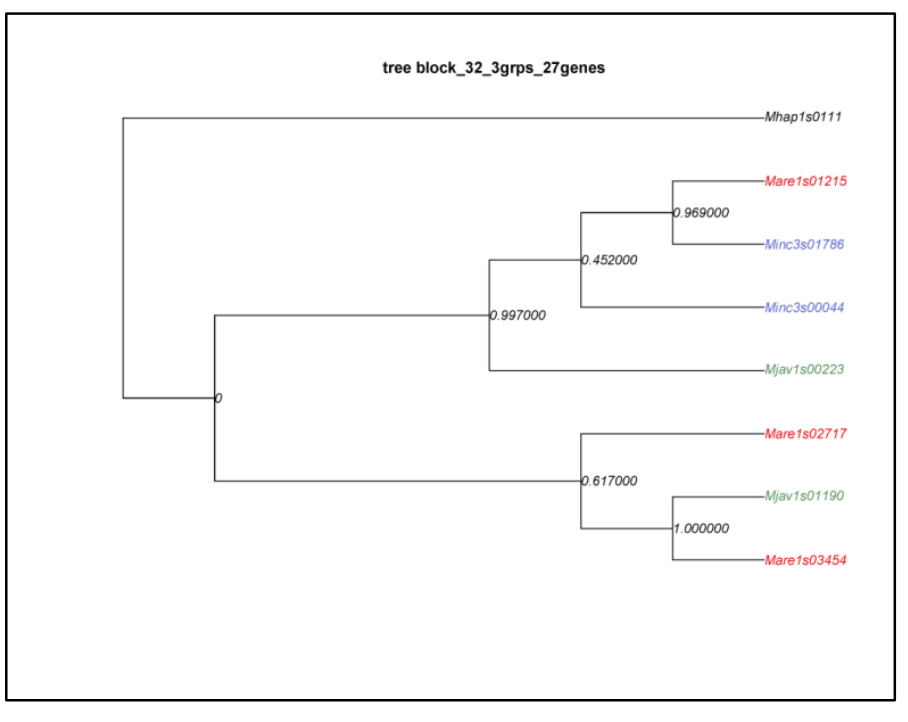



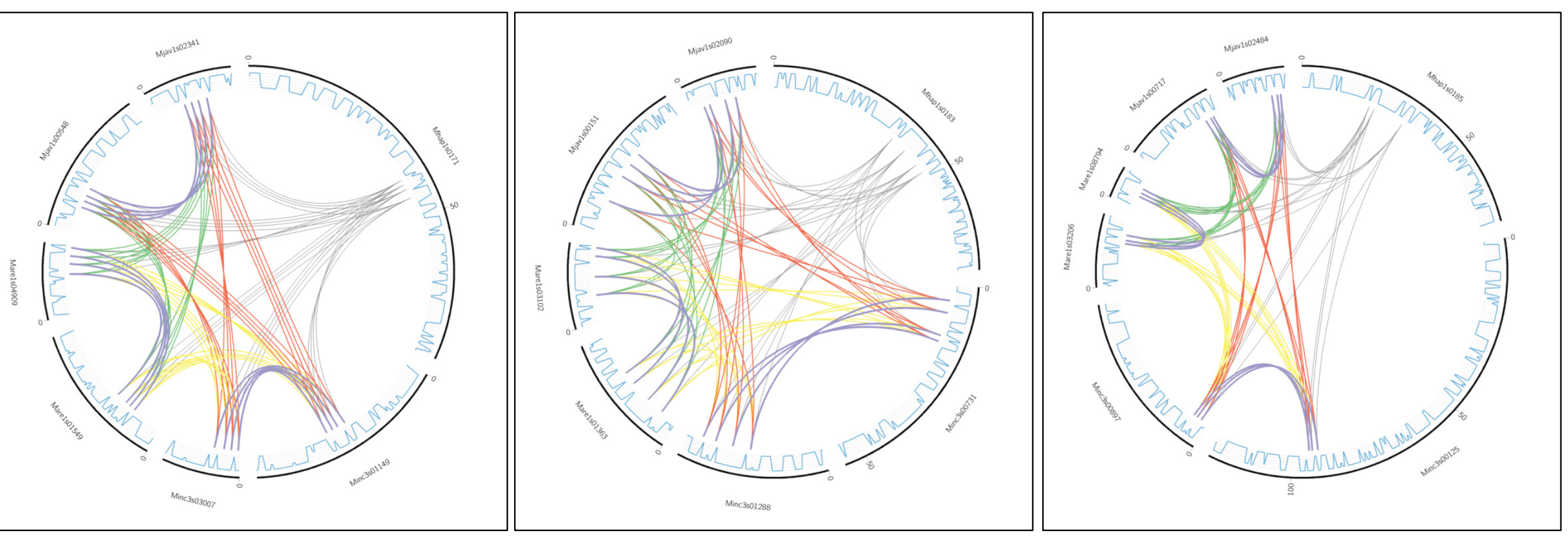

tree block_39_4grps_32genes

\section{No tree}

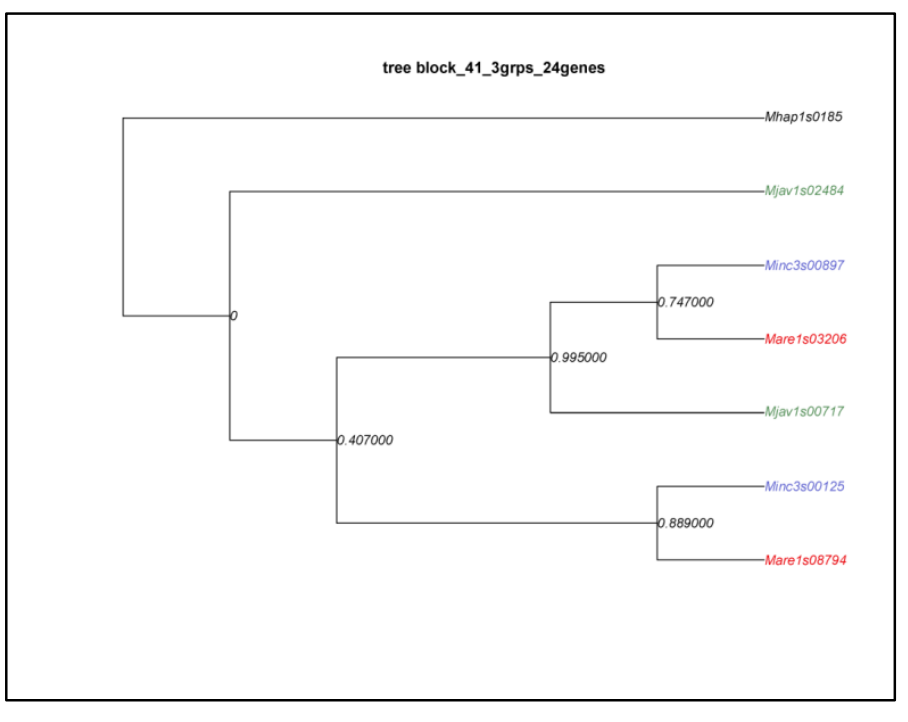



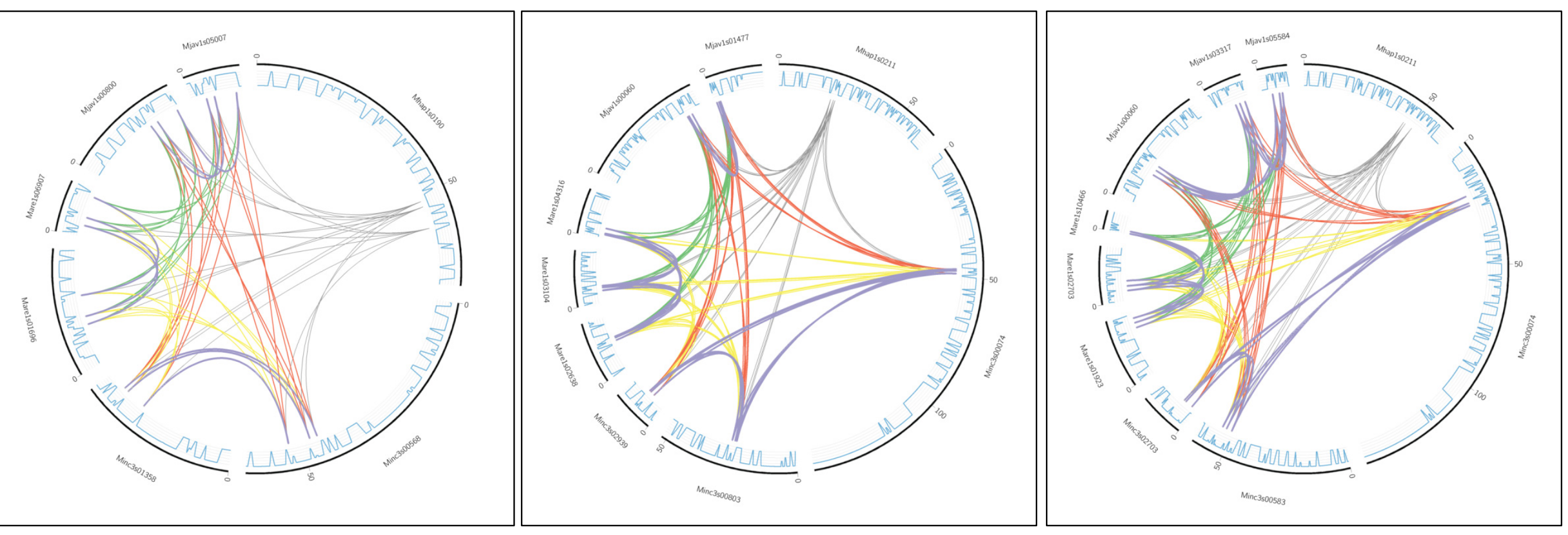

\section{No tree}
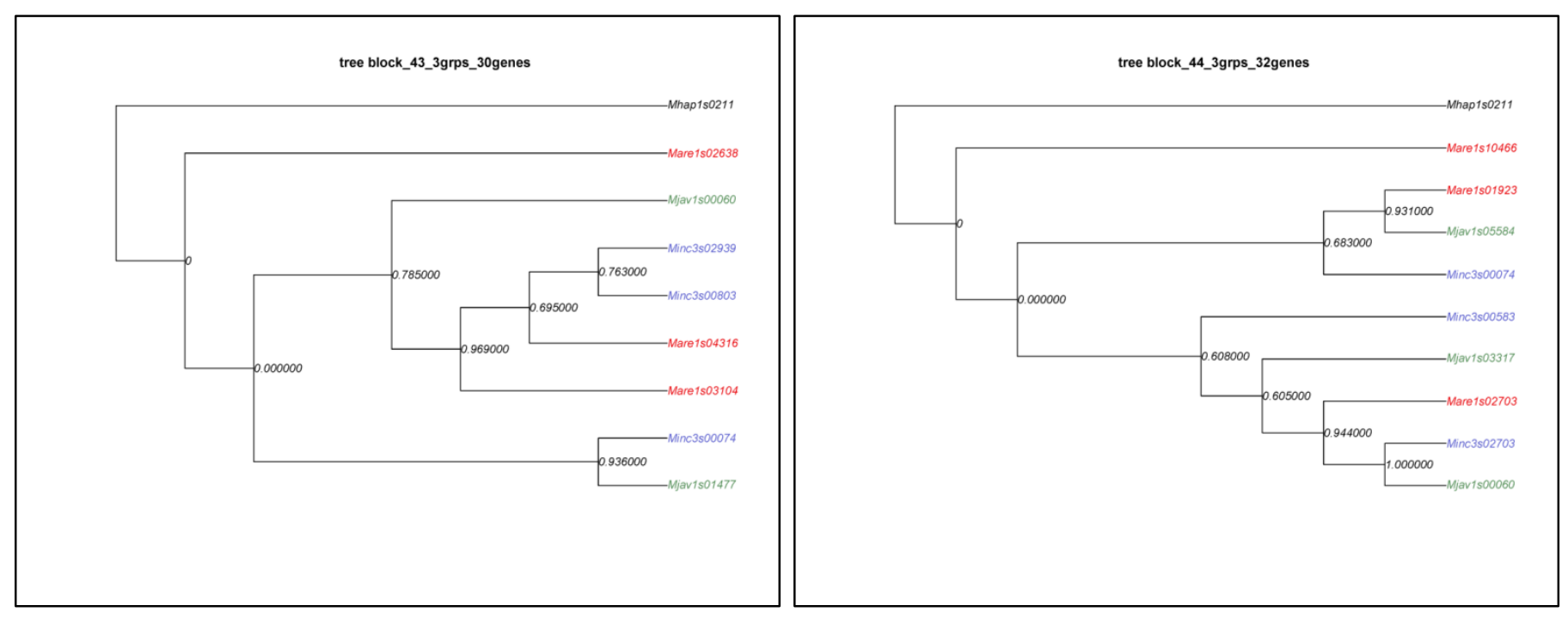

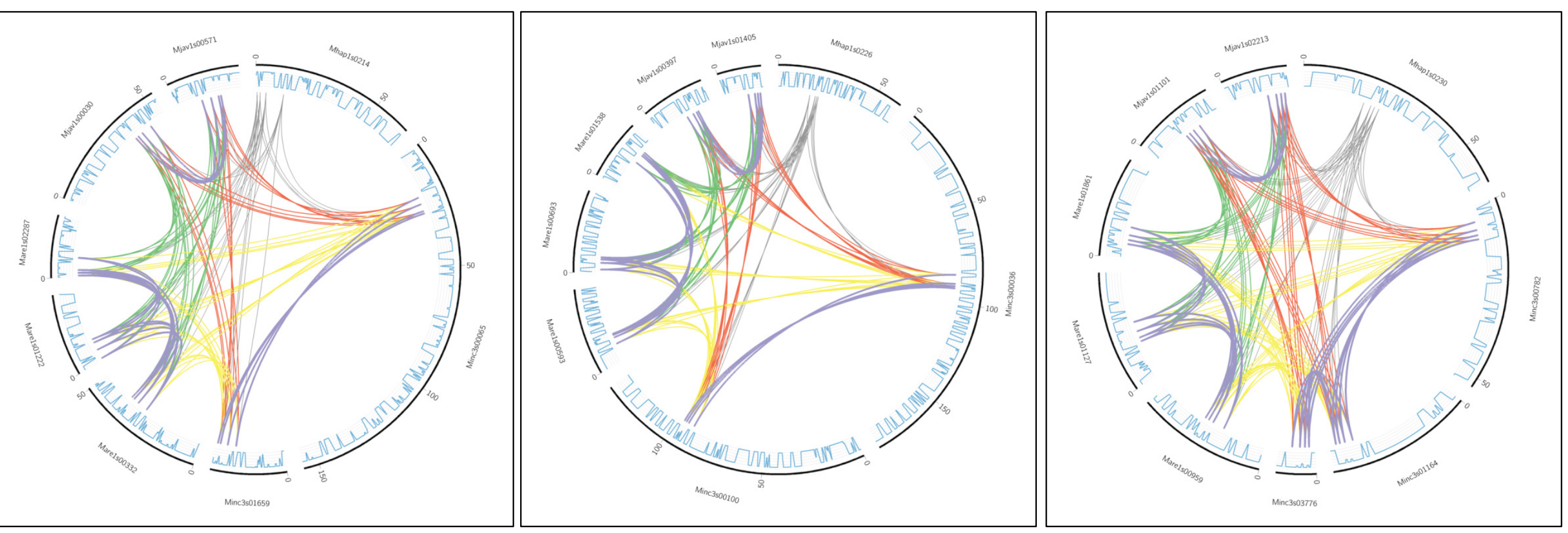

\section{No tree}
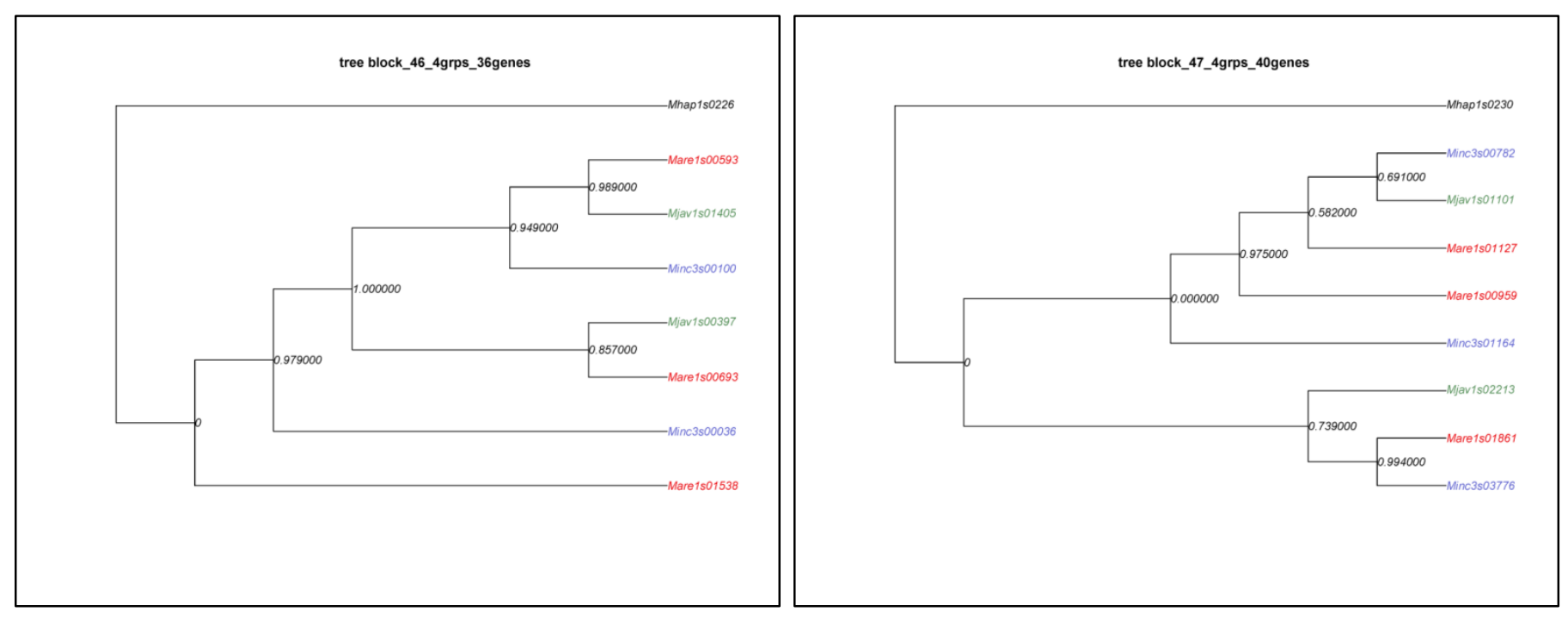

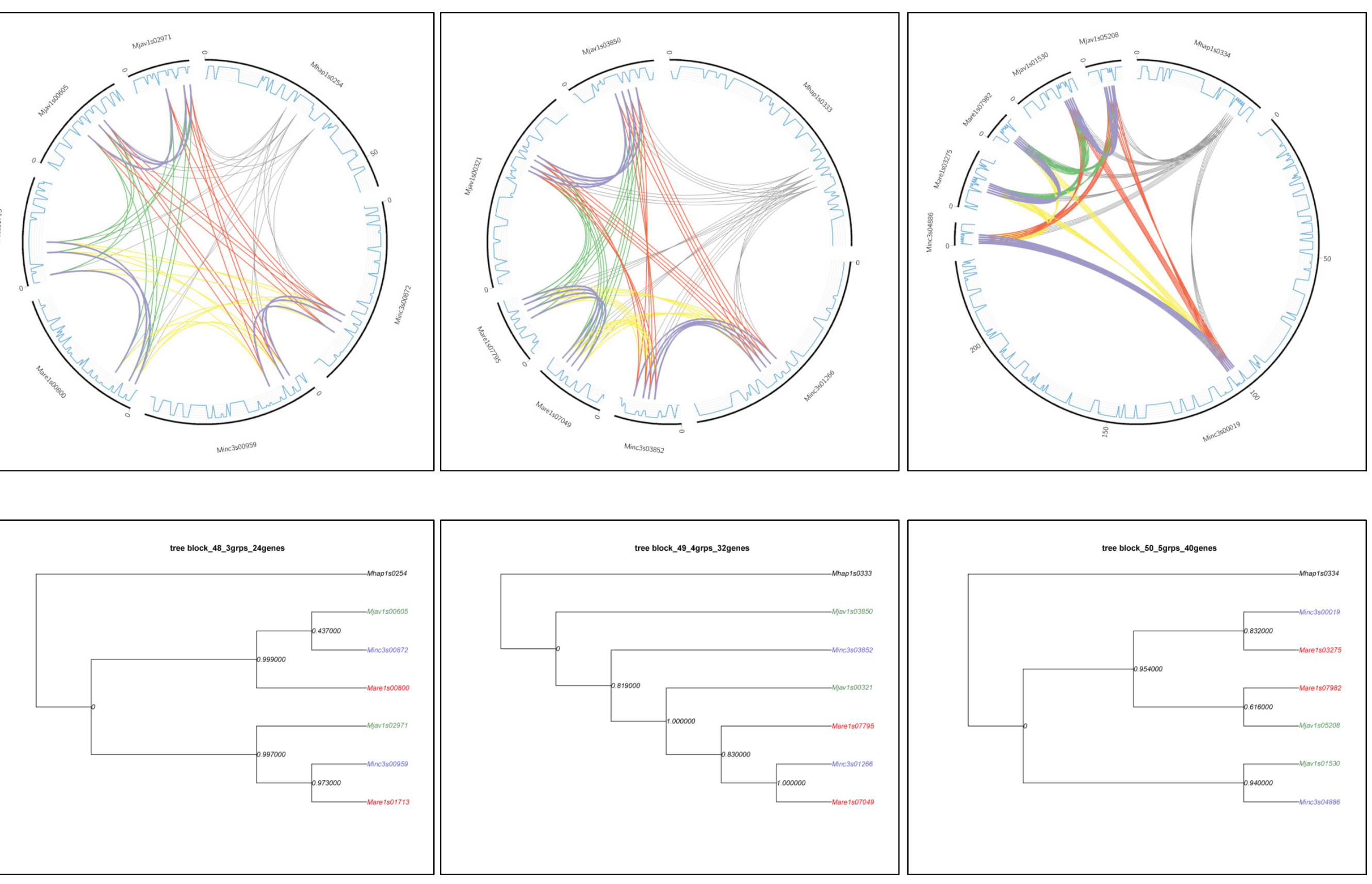

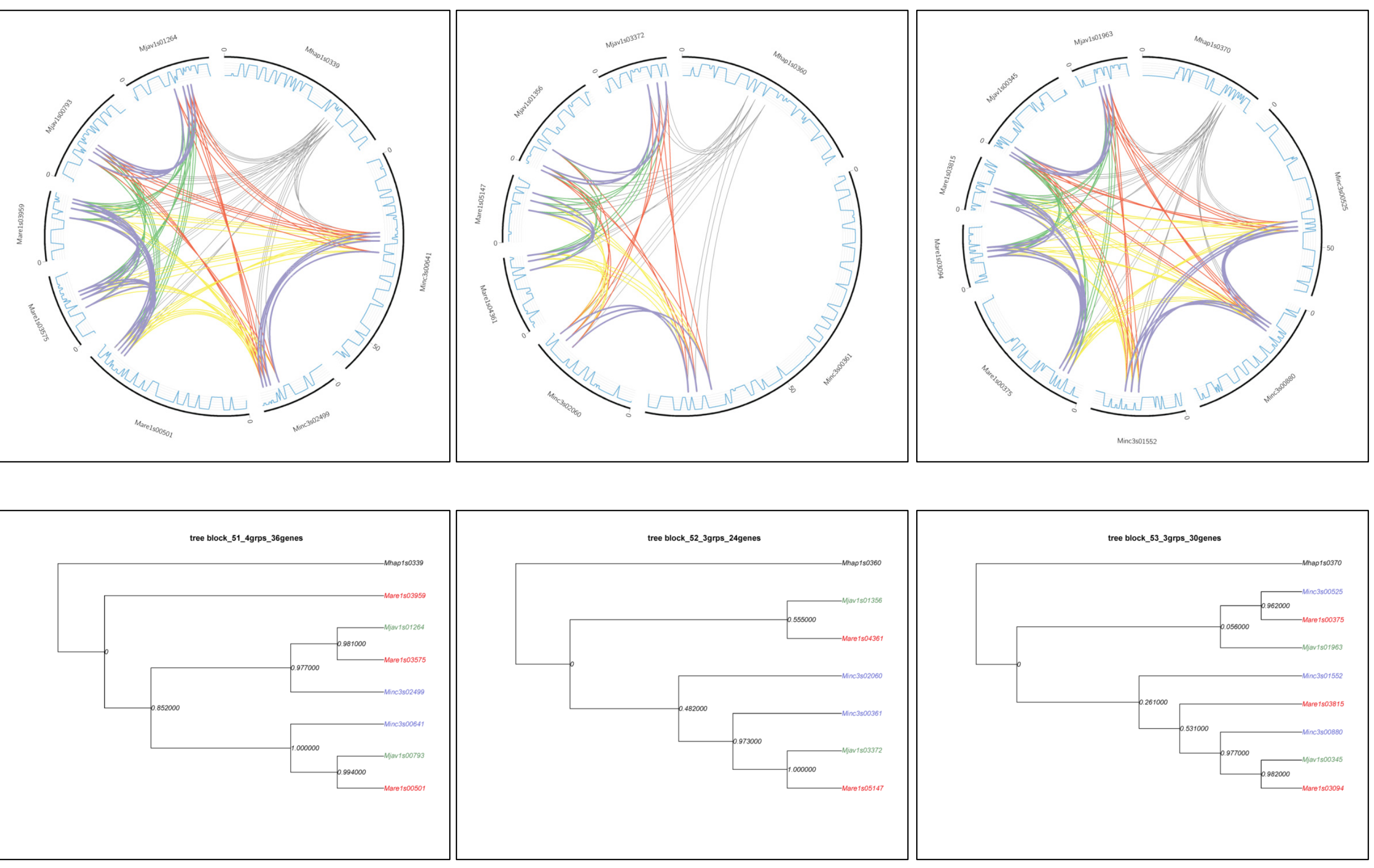

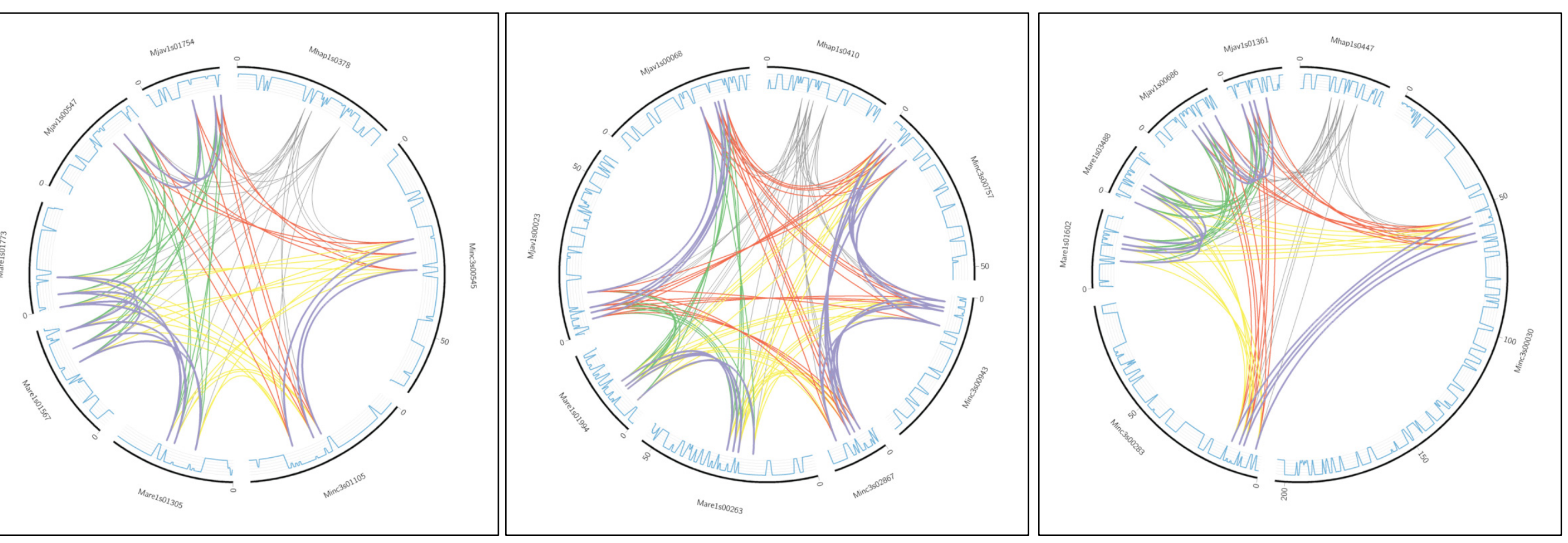

tree block_54_3grps_27genes

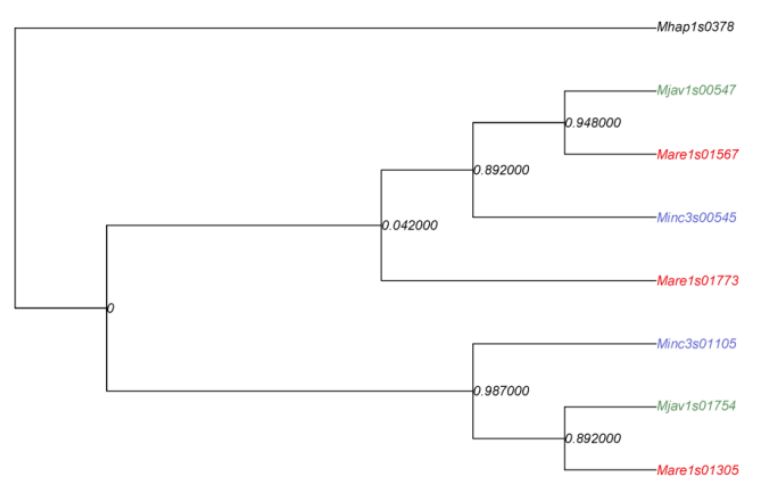

tree block_55_4grps_36genes

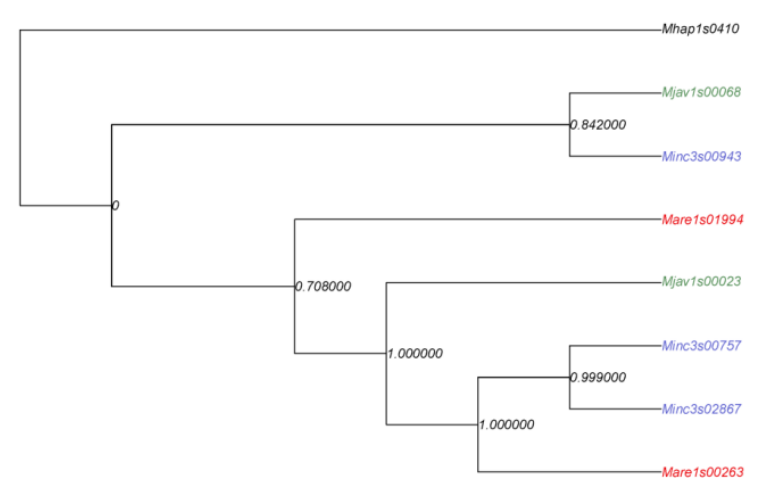

tree block_56_4grps_32genes

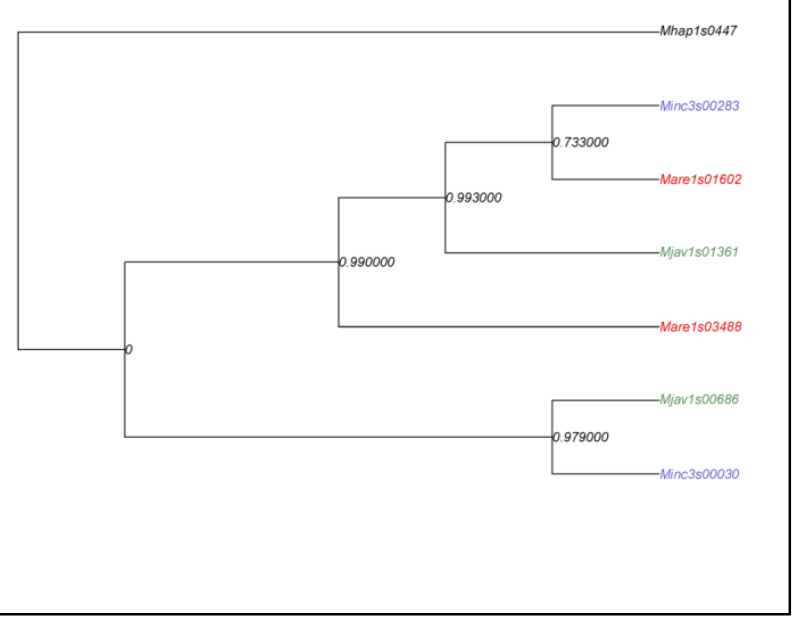


